\title{
Perancangan Sistem Aplikasi Monitoring Barang menggunakan Barcode Berbasis Android. (study kasus Toko Chacha cell ITC Cempaka mas)
}

\author{
Rian gustini 1), Firman Noor Hasan ${ }^{2}$ \\ 1,2)Teknik Informatika Fukultas Teknik Universitas Muhammadiyah Prof. Dr. Hamka \\ Jl. Tanah Merdeka No.6, Pasar Rebo, Jakarta Timur Telp: 021-8778.2739, Mobile: 0813.1140.6664 \\ Website:www.ft.uhamka.ac.id, E-mail: riangustni@gmail.com ${ }^{1)}$, firman.noorhasan@uhamka.ac.id ${ }^{2}$
}

\begin{abstract}
Abstrak - Cha-cha cell ITC Cempaka Mas adalah salah satu Toko jual beli Handphone yang belum memanfaatkan sistem database yang terkomputerisasi sehingga masih memeriksa harga dan stok barang secara manual dan database penjualannyapun masih menggunakan buku-buku tebal. Proses pengecekan ini yang membuat transaksi jual beli menjadi lama karena pengecekan barang dan harga masih dilakukan secara manual. Oleh karena itu penulis merancang sebuah aplikasi yang memudahkan dalam pengecekan stok barang. Aplikasi ini dirancang menggunakan metode prototyping di uji dengan metode uji Black box, dan dari hasil wawancara dengan owner beserta karyawan aplikasi ini mampu memudahkan karyawan dalam mengecek stok barang jual dan barang beli.
\end{abstract}

Kata kunci: android, app Inventor, database, MySQL.

\begin{abstract}
Cha-cha cell ITC Cempaka Mas is one of the mobile buying and selling stores that have not utilizes a computerized database system so that it still checks the price and stock of items manually and the sales database is still using thick books. This checking process makes buying and selling transactions take a long time because checking items and prices are still done manually. Thereforelthat's why, the author approves an application that makes it easy to check inventory. This application uses the prototyping method which is tested by the Black Box test method and from the results of interviews with the owner regarding the application that provides employees in checking stock of items sold and items bought.
\end{abstract}

Keyword: android, app Inventor, database, MySQL.

\section{PENDAHULUAN}

Cha-cha cell ITC Cempaka Mas adalah salah satu Toko jual beli Handphone yang belum memanfaatkan sistem database yang belum terkomputerisasi, sehingga masih memeriksa harga dan stok barang secara manual, dan database penjualannyapun masih menggunakan buku-buku tebal. Proses pengecekan ini yang membuat transaksi jual beli menjadi lama karena pengecekan barang dan harga masih dilakukan secara manual.

Inventory merupakan suatu aset yang berbentuk barang-barang yang dimiliki untuk dijual dalam toko maupun barang-barang yang sedang dalam proses pembuatan. Manajemen inventory merupakan pengaturan persediaan barang dengan tujuan kelancaran usahanya [1]. Sistem basis data sangat dibutuhkan dalam pengelolaan inventory atau penyimpanan barang, komponen dasar dari semua aplikasi-aplikasi dalam sebuah sistem informasi yaitu basis data. Data Warehouse merupakan database relasional yang rancang lebih condong kepada analisa Dipresentasikan pada Tanggal 28 November 2020 Copyright (C) 2020 FT - UHAMKA. - All rights reserved dan query dari pada proses transaksi, dan biasanya mengandung history data dari proses transaksi dan bisa juga data dari sumber lainnya[2]. Program-program tersebut digunakan untuk berinteraksi dengan pengguna terutama untuk menyajikan informasi yang diperlukan dan untuk menangkap informasi dari pengguna [3] sehingga sangat diperlukan untuk proses jual beli.

Berdasarkan masalah yang terjadi. penulis tertarik dengan masalah tersebut, dan dijadikan usulan penelitian dengan judul : "PERANCANGAN

SISTEM APLIKASI MONITORING BARANG MENGGUNAKAN BARCODE BERBASIS ANDROID (STUDI KASUS CHA-CHA CELL ITC CEMPAKA MAS) “.

Aplikasi yang akan digunakan untuk smartpone terutama untuk versi Android ini akan memanfaatkan system barcode dengan bantuan aplikasi pendukung yaitu Barcode Scanner dan dikoneksikan langsung ke database toko. Pembacaan barcode dilakukan 
menggunakan barcode scanner kemudian setelah itu data masuk ke database pada komputer server utama, kemudian data bisa diambil dan diakses via android. Aplikasi ini diharapkan akan mudah digunakan oleh user untuk melihat berapa barang yang masih tersedia, barang masuk dan berapa barang yang keluar. Juga untuk memudahkan karyawan dalam pembuatan laporan dengan sistem yang terkomputerisasi. Sehingga dalam proses jual beli juga semakin cepat, tidak memerlukan waktu yang lama, dan proses pembuatan laporan bulanan lebih mudah dan cepat.

\section{DASAR TEORI}

\subsection{Barcode}

Barcode adalah suatu kumpulan data optik yang dibaca mesin.Sebenarnya, kode batang ini mengumpulkan data dalam lebar (garis) dan jarak garis paralel atau disebut sebagai simbologi linear atau ID (1 dimensi) Tetapi ada juga yang memiliki bentuk persegi, titik, heksagon, dan bentuk geometri lainnya didalam gambar yang disebut kode matriks atau simbologi 2D (2 dimensi)[4].

\subsection{Monitoring}

Monitoring merupakan proses analisis dan pengumpulan informasi berdasarkan parameter yang ditetapkan secara tersusun dan berkelanjutan tentang program/ kegiatan serta tindakan untuk penyempurnaan program/ kegiatan itu dilakukan dengan evauasi/koreksi[5].

\subsection{Inventory}

Persediaan merupakan simpanan material yang bisa berupa barang dalam proses bahan mentah, barang yang masih diproses, dan barang yang sudah jadi. Mempermudah jalannya operasi perusahaan yang dilakukan secara berturut-turut untuk proses bisnis yang merupakan fungsi Persediaan [6].

\subsection{Android}

Sistem operasi open source yang berbasis linux dengan platform terbuka bagi para pengembang untuk menciptakan aplikasi baru biasa dikenal sebagai Android. Kode

Android dirilis oleh Google dinaungi Lisensi Apache. Kode dengan operasi open source dan lisensi perizinan pada Android memungkinkan perangkat lunak untuk dimodifikasi secara bebas dan didistribusikan oleh para pembuat perangkat, operator nirkabel, dan pengembang aplikasi [6].

\subsection{App Inventor}

Copyright $(2020$ FT-UHAMKA. - All rights reserved DOI:10.22236/teknoka.v5i.319
App Inventor adalah software untuk membuat aplikasi pada perangkat android. App Inventor bekerja dengan interaksi visual berbasis grafis. Dalam hal ini, App Inventor dapat disebut sebagai sistem terpadu untuk mengembangkan aplikasi berbasis blog-blog [7].

\subsection{MySql}

MySQL merupakan software yang dapat mengolah database dengan sangat cepat, dapat menampung data dalam jumlah sangat besar, dapat diakses oleh banyak pengguna dan dapat melakukan suatu proses secara bersamaan [8].

\subsection{Database}

Pengertian database menurut Bambang Hariyanto (2004) yaitu kumpulan data (elementer) yang secara logic berkaitan dalam mempresentasikan fakta/fenomena yang secara terstruktur dalam domain tertentu untuk mendukung aplikasi dalam system tertentu. Dari uraian tersebut maka dapat disimpulkan bahwa database merupakan kumpulan dari item data yang

Pengaturan data atau arsip adalah Prinsip utama dari basis data. Tujuan utamanya untuk kecepatan dan kemudahan kecepatan dalam pengambilan data [9].

\section{METODOLOGI PENELITIAN}

Metode yang akan digunakan pada penelitian ini yaitu metode Prototype, pada metode prototype terjadi kerjasama antara developer dan pengguna sistem guna untuk menentukan tujuan, fungsi dan kebutuhan operasional sistem.

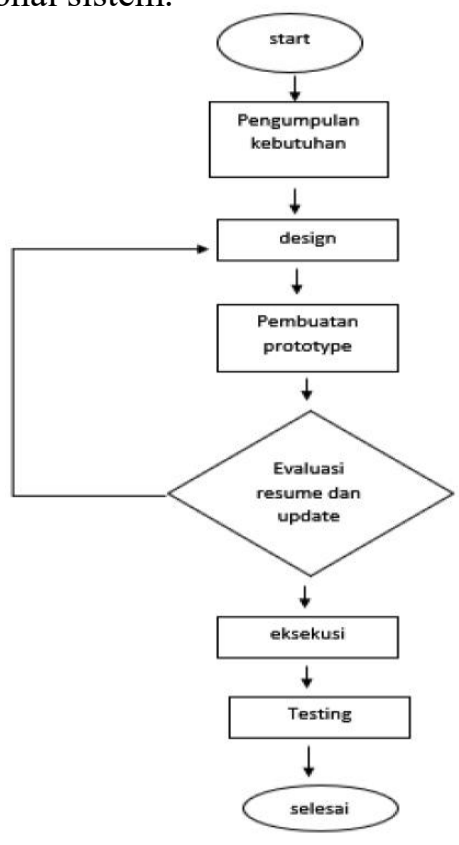

Gambar 3.1 diagram alir

Seminar Nasional TEKNOKA ke - 5, Vol. 5, 2020 ISSN No. 2502-8782 


\subsection{Pengumpulan Kebutuhan}

Dalam tahap ini pengumpulan kebutuhan dan permasalahan didapatkan dari media wawancara dengan pihak owner Cha-cha Cell. Tujuannya untuk mengetahui kebutuhan user, sehingga penulis dapat membuat aplikasi yang sesuai keinginan, dan sesuai dengan kebutuhan user.

\subsection{Design}

Pada tahap ini yang design dibuat sesuai dengan kebutuhan, dan keinginan yang sudah dibuat ditahap sebelumnya.

\subsection{Prototype}

Selanjutnya pembuatan prototype ini dibuat untuk menjadi gambaran seperti apa aplikasi, dan sistem seperti apa yang akan dibuat.

\subsection{Evaluasi consumen, Review, dan Update}

Setelah tahap prototype selesai, maka akan dikaji ulang oleh developer dan consumen agar sesuai dengan yang diharapkan dan dibutuhkan. Setelah mengevaluasi maka memasuki tahap review guna untuk mengulas kekurangan, dan penyusunan ulang apabila terdapat hal yang perlu dirubah setelah dievaluasi oleh consumen. Apabila terjadi perubahan maka akan dibuat design ulang sampai semuanya sesuai dengan kesepakatan consumen, dan developer.

\section{5 Eksekusi}

Setelah tidak terdapat lagi evaluasi maka akan masuk ketahap eksekusi dan pembuatan aplikasi. Pada tahap ini menggunakan apikasi APP inventor untuk pengodean pembuatan aplikasi berbasis android. Sedangkan untuk database menggunakan MYSQL dan PHPmy Admin.

\subsection{Testing}

Pada tahap ini aplikasi yang sudah dibuat akan ditest kelayakannya menggunakan Black box testing, metode testing yang memungkinkan rekayasa perangkat lunak yang dimana kondisi input yang sepenuhnya menggunakan semua persyaratan fungsional untuk suatu program.

\section{PERANCANGAN SISTEM}

\subsection{Use case}

Perancangan use case diagram ini digunakan untuk memahami interaksi dan kegiatan antara user dan sistem. Use case yang ditunjukkan pada Gambar 4.1 menjelaskan tentang interaksi antara karyawan dan juga Owner Cha-cha cell dengan sistem, mulai dari proses awal dari login hingga selesai.

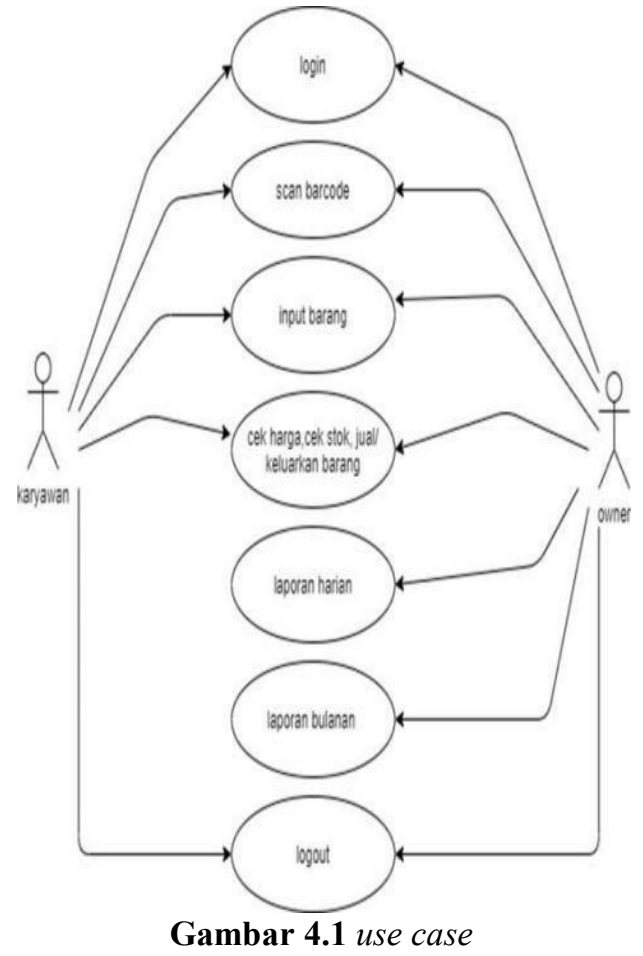

\subsection{Class Diagram}

Class diagram ini dibuat untuk mengetahui hubungan antar kelas-kelas database yang terhubung satu sama lain pada sistem aplikasi ini. Berikut adalah class diagram dari sistem aplikasi ini pada gambar 4.2.

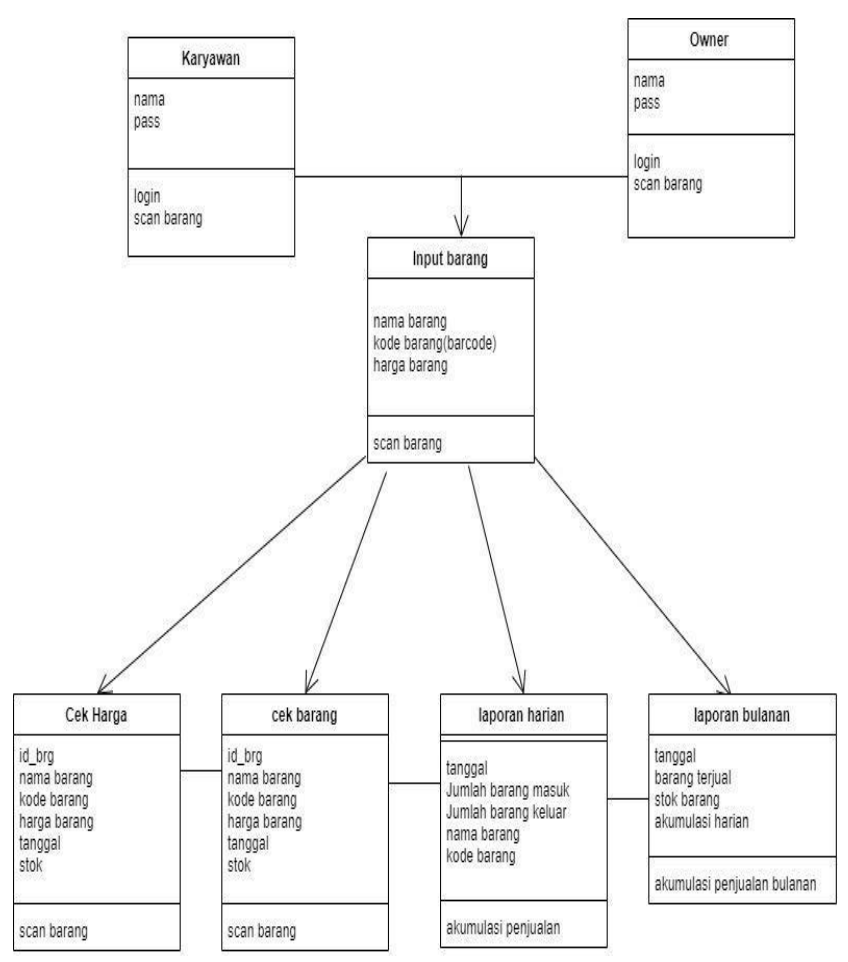

Gambar 4.2 class diagram 


\section{HASIL}

\subsection{Login}

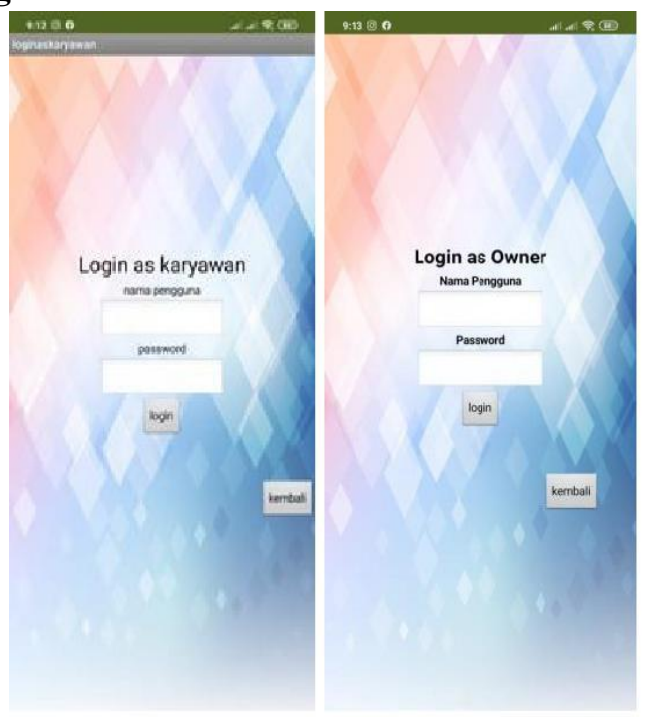

Gambar 5.1 Tampilan login

Halaman ini merupakan halaman yang paling awal muncul ketika pengguna membuka aplikasi. Terdapat dua pilihan yaitu login as owner untuk hak akses owner yaitu login as karyawan untuk hak akses karyawan.

\subsection{Menu}

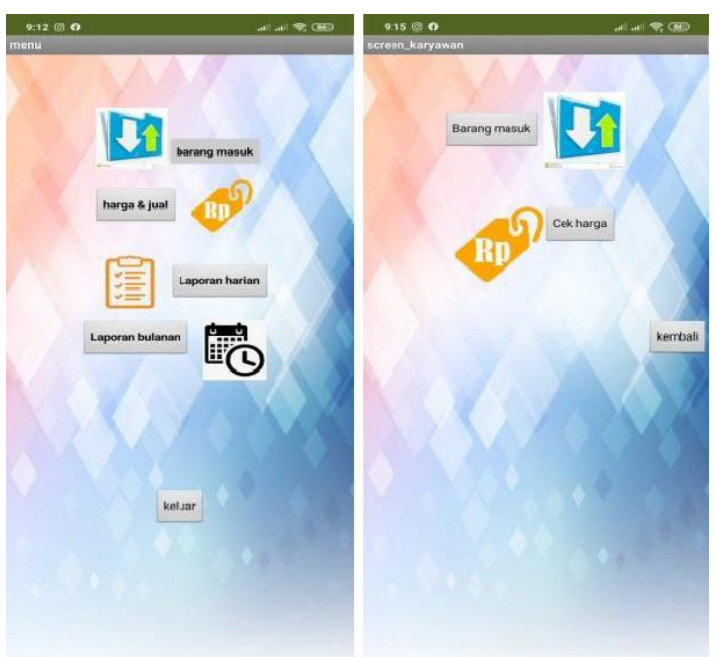

Gambar 5.2 Tampilan menu

Ini adalah tampilan menu yang akan keluar setelah pengguna melakukan login, terdapat dua menu ada beberapa pilihan yaitu barang masuk untuk masuk ke menu input barang atau barang masuk, cek harga untuk masuk ke menu harga untuk melihat stok, cek harga, jual barang, dan kembali untuk kembali ke menu utama.

\subsection{Masukkan Barang}

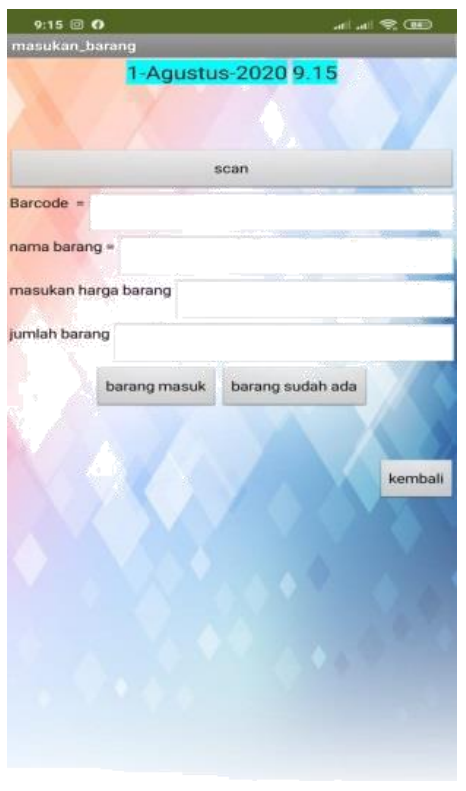

Gambar 5.3 Tampilan Hasil

Halaman ini berisi empat kolom dan tiga pilihan, pilihan scan barcode untuk scan barcode dan mendapatkan kode barang, lalu ada kolom untuk mengisi nama barang harga, dan jumlah barang yang masuk. Serta ada pilihan barang masuk untuk menginput barang yang belum pernah terinput, pilihan barang yang sudah ada untuk menginput barang yang sudah pernah terinput, dan tombol kembali untuk kembali ke halaman sebelumnya.

\subsection{Cek harga stok dan jual}

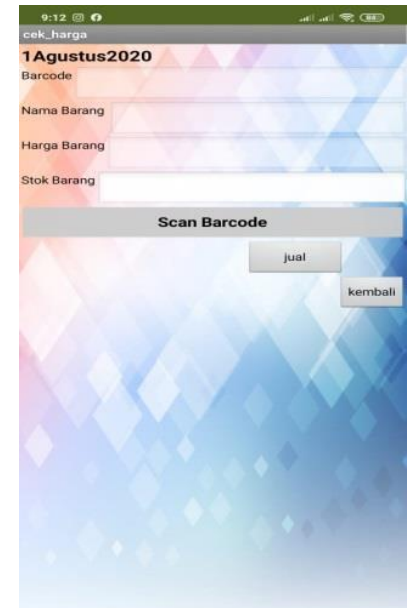

Gambar 5.4 Tampilan cek harga dan jual

Pada halaman ini scan barcode untuk mendapatkan kode barang serta menampilkan output dari masing-masing kolom sesuai fungsinya, botton jual untuk menjual barang, Serta tombol kembali untuk kembali ke halaman sebelumnya. 


\subsection{Laporan Bulanan}

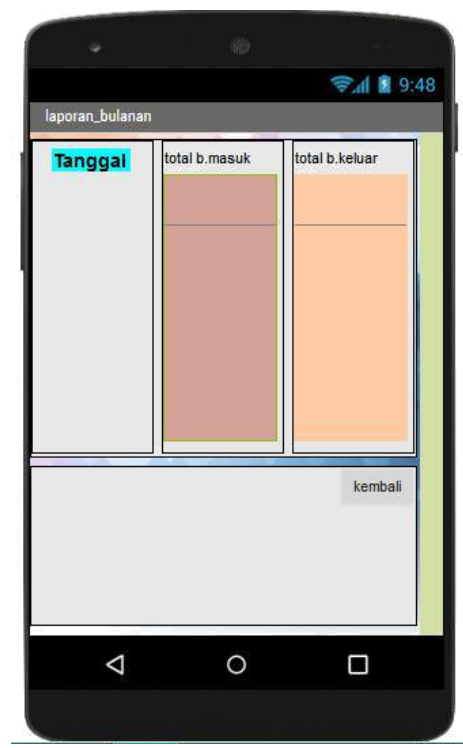

Gambar 5.5 Tampilan Laporan Bulanan

Laporan bulanan adalah halaman untuk menunjukan laporan pembelian dan penjualan barang dalam periode perbulan.

\subsection{Laporan Harian}

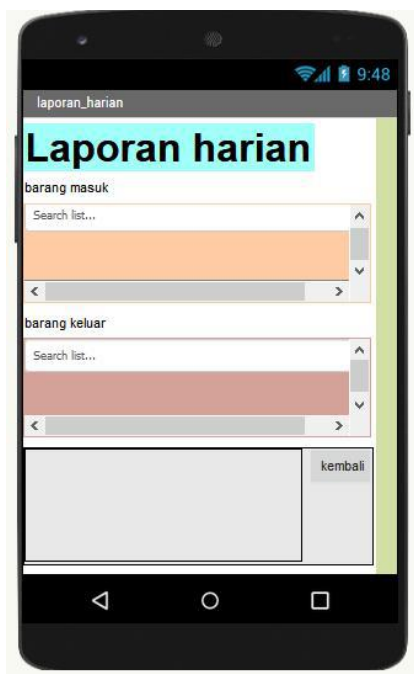

Gambar 5.6 Tampilan Laporan harian

Menu laporan harian adalah halaman untuk menunjukan laporan pembelian dan penjualan barang perhari

\section{SIMPULAN}

Setelah selesai melakukan perancangan dan pembahasan yang telah diuraikan, maka dapat diambil kesimpulan sebagai berikut:

1. Penulis telah berhasil merancang dan membangun sistem aplikasi monitoring menggunakan barcode.
Aplikasi ini Bisa menginput barang, laporan barang masuk dan keluar, cek harga dan stok, menampilkan laporan harian dan Bulanan.

2. Aplikasi ini sudah membantu memeriksa stok barang dan harga lebih cepat, serta pembukuan atau database sudah terkomputerisasi. Karena menurut hasil wawancara karyawan dan owner yang telah mencoba aplikasi ini, memudahkan mereka memeriksa stok barang dan memudahkan mereka untuk menginput laporan stok barang sehingga tujuan dari perancangan aplikasi ini sudah tercapai.

\section{KEPUSTAKAAN}

[1] A. E. Syaputra, "Journal of Information and Technology," J. Inf. Technol., vol. 53, no. 9, ap. 1689-1699, 2019, doi: 10.1017/CBO9781107415324.004.

[2] F. N. Hasan, "Implementasi Sistem Business Intelligence Untuk Data Penelitian di Perguruan Tinggi," in Prosiding Seminar Nasional TEKNOKA 4, 2019, doi: 10.22236/teknoka.v4i1.3943.

[3] H. Maulana, "Analisis Dan Perancangan Sistem Replikasi Database Mysql Dengan Menggunakan Vmware Pada Sistem Operasi Open Source," InfoTekJar (Jurnal Nas. Inform. dan Teknol. Jaringan), vol. 1, no. 1, ap. 32-37, 2016, doi: 10.30743/infotekjar.v1i1.37.

[4] R. Perdana, Sandy; Wulandari Sri Hariani Eko; Santoso, "Rancang Bangun Aplikasi Penjualan Barang Pada Toko," vol. 5, no. 12, ap. 1-5, 2016.

[5] Suparni and Hadiyansyah, "Sistem Informasi Monitoring Inventory IT Aset ( SIMONAS ) Berbasis Web Pada PT . Metrocom Global Solusi Jakarta," J. Penelit. Tek. Inform., vol. 3, no. 1, pp. 91-98, 2018.

[6] W. Nugraha et al., "PENERAPAN METODE PROTOTYPE DALAM PERANCANGAN SISTEM INFORMASI PENGHITUNGAN VOLUME DAN COST PENJUALAN," vol. 03, no. 02, pp. 97-105, 2018.

[7] R. D. Axel, X. Najoan, B. A. Sugiarso, J. T. Elektro-ft, and M. Manado, "Rancang Bangun Aplikasi Berbasis Android Untuk Informasi Kegiatan Dan Pelayanan Gereja," E-Journal Tek. Elektro Dan Komput., vol. 6, no. 1, pp. 1-6, 2017, doi: 10.35793/jtek.6.1.2017.15566. 
[8] T. Rahmasari, "Perancangan Sistem Informasi Akuntansi Persediaan Barang Dagang Pada Toserba Selamat Menggunakan Php Dan Mysql," is Best [Accounting Inf. Syst. Inf. Technol. Bus. Enterp., vol. 4, no. 1, pp. 411425, 2019, doi:

10.34010/aisthebest.v4i1.1830.
[9] I. P. A. Putra Yudha, M. Sudarma, and P. Arya Mertasana, "Perancangan Aplikasi Sistem Inventory Barang Menggunakan Barcode Scanner Berbasis Android," $J$. SPEKTRUM, vol. 4, no. 2, p. 72, 2018, doi: 10.24843/spektrum.2017.v04.i02.p10. 